\title{
Cleaning up the grasses dustbin: systematics of the Arundinoideae subfamily (Poaceae)
}

\author{
Laurent Hardion ${ }^{1}$, Régine Verlaque ${ }^{2}$, Gisèle Haan-Archipoff ${ }^{3}$, Daniel Cahen ${ }^{4}$, Michel Hoff $^{3}$, Bruno \\ Vila ${ }^{2}$
}

${ }^{1}$ Laboratoire Image Ville Environnement (LIVE), University of Strasbourg, CNRS, Institut de Botanique, 28 rue Goethe, 67000 Strasbourg, France

${ }^{2}$ Institut Méditerranéen de Biodiversité et d'Écologie (IMBE), UMR CNRS, IRD, Aix-Marseille University, Avignon University, Marseille, France

${ }^{3}$ Herbarium of the University of Strasbourg (STR), Faculty of Life Sciences, Strasbourg, France

${ }^{4}$ Herbarium, Royal Botanic Gardens, Kew, Richmond, UK

Corresponding author: Laurent Hardion, hardion@unistra.fr

\begin{abstract}
Among the 12 subfamilies currently considered in the systematics of Poaceae, the Arundinoideae have long been considered as a dustbin group, with a diversity of forms putatively hiding incertae sedis. Because this subfamily has been poorly investigated using molecular markers for the last two decades, the present study provides the first complete phylogeny of the Arundinoideae based on five plastid DNA loci sequenced for 12 genera, and analysed with and without plastome data from previous studies. The refined Arundinoideae appear to be a robust evolutionary lineage of Poaceae, divided into three tribes with some biogeographical patterns: (1) tribe Arundineae, the most heterogeneous tribe, including Eurasian Arundo, Australian Amphipogon and Monachather, and South African Dregeochloa; (2) tribe Crinipedeae (described here), including Crinipes, Elytrophorus, Styppeiochloa and Pratochloa (described here), with a South and East African distribution; and (3) tribe Molinieae, including Hakonechloa, Molinia and Phragmites, with a Eurasian distribution. Despite reduction in size, this small subfamily conserves a high diversity of morphological forms, with several small but highly differentiated genera. Finally, the molecular dating approach provides an evolutionary framework to understand the diversification of Arundinoideae, refuting Gondwanan vicariance between genera and suggesting capability for long distance dispersal.
\end{abstract}

Keywords Arundo, Crinipedeae, Phragmites, Phylogeny, Pratochloa, Taxonomy 


\section{Introduction}

Poaceae Barnhart is one of the most fascinating plant families by its usefulness for humans and its ecological and taxonomic diversification. Although several angiosperm families possess higher species richness, grasses exceed all others by their ecological significance (Kellogg 2000). Thanks to numerous adaptive strategies such as $\mathrm{C}_{-4}$ metabolism (GPWG II 2012), Poaceae occur in almost all terrestrial ecosystems and dominate grassland biomes covering a quarter of land surfaces (Shantz 1954). In addition, about half of the annual production of global agriculture is due to the domestication of four of the $c .12,000$ grass species (http://faostat.fao. org/). In this context, the understanding of grass evolutionary history represents a major scientific challenge. Since the groundwork studies by Brown $(1810,1814)$, Poaceae have been periodically revised in several subfamilies and tribes (a synthesis in Prat 1960; Clayton and Renvoize 1986). For the last two decades, molecular studies have accelerated this systematics resolution (Clark et al. 1995; Duvall and Morton 1996 ; Hilu et al. 1999; Hsiao et al. 1999; GPWG 2001), with the current consideration of 12 subfamilies, 51 tribes and 771 genera (Soreng et al. 2015), structured in two main lineages, the BOP and PACMAD clades (Fig. 1).

Arundinoideae Kunth ex Beilschm. were dissociated from these two historical lineages early on, due to apically reduced florets and laterally compressed spikelets-specific to the 'festucoid' type-versus subtropical distribution and epidermal features-specific to the 'panicoid' type (Avdulov 1931; Jacques-Félix 1958; Stebbins and Crampton 1959; Prat 1960; Fig. 1a). Arundinoideae included incertae sedis taxa, which sometimes led to consider it to be a basal clade of Poaceae, or even a taxonomic 'dustbin group' (Prat 1960; Auquier 1963; Clayton and Renvoize 1986). Consequently, Arundinoideae have included up to 736 species and 72 genera (Conert 1961, 1966; Renvoize 1981; Soreng et al. 2015), but its molecular polyphyly (Barker et al. 1995, 1998; Hsiao et al. 1998) led to its drastic reduction by the description of Danthonioideae H.P.Linder \& N.P.Barker (GPWG 2001) and the reinstatement of Micrairoideae Pilg. (Sánchez-Ken et al. 2007).

Following these treatments, Arundinoideae have become one of the smallest grass subfamilies, with 15 genera and about 42 species (Table 1). But these taxa show a surprising ecological and morphological heterogeneity, from helophyte reeds such as Phragmites australis (Cav.) Trin. ex Steud., one of the most cosmopolitan plant species, to dwarf xerophytes such as Dregeochloa pumila (Nees) Conert, the only succulent grass living in Southern African sandy deserts. Repeated morphological analyses of Arundinoideae provided some interesting insights but failed to clearly resolve their classification. This is partly due to the diversity of forms and few evident synapomorphies in such a small subfamily (Renvoize 1981; Linder et al. 1997 ). In addition, several taxa currently in the Arundinoideae may be erroneously included. In return, some apparent Arundinoideae may be misplaced in other subfamilies, such as 'Eragrostis walteri Pilg.' previously considered as the only non- $\mathrm{C}_{4}$ Chloridoideae, but recently placed in the Arundinoideae based on molecular 
data (Ingram et al. 2011). Finally, several species and genera (Dichaetaria Nees ex Steud., Leptagrostis C.E.Hubb., Nematopoa C.E.Hubb. Piptophyllum C.E.Hubb., Zenkeria Trin.) of Arundinoideae have never been studied in a molecular phylogeny, due to their rarity and restricted distributions, some of them being represented only by a few herbarium specimens (Linder et al. 1997).

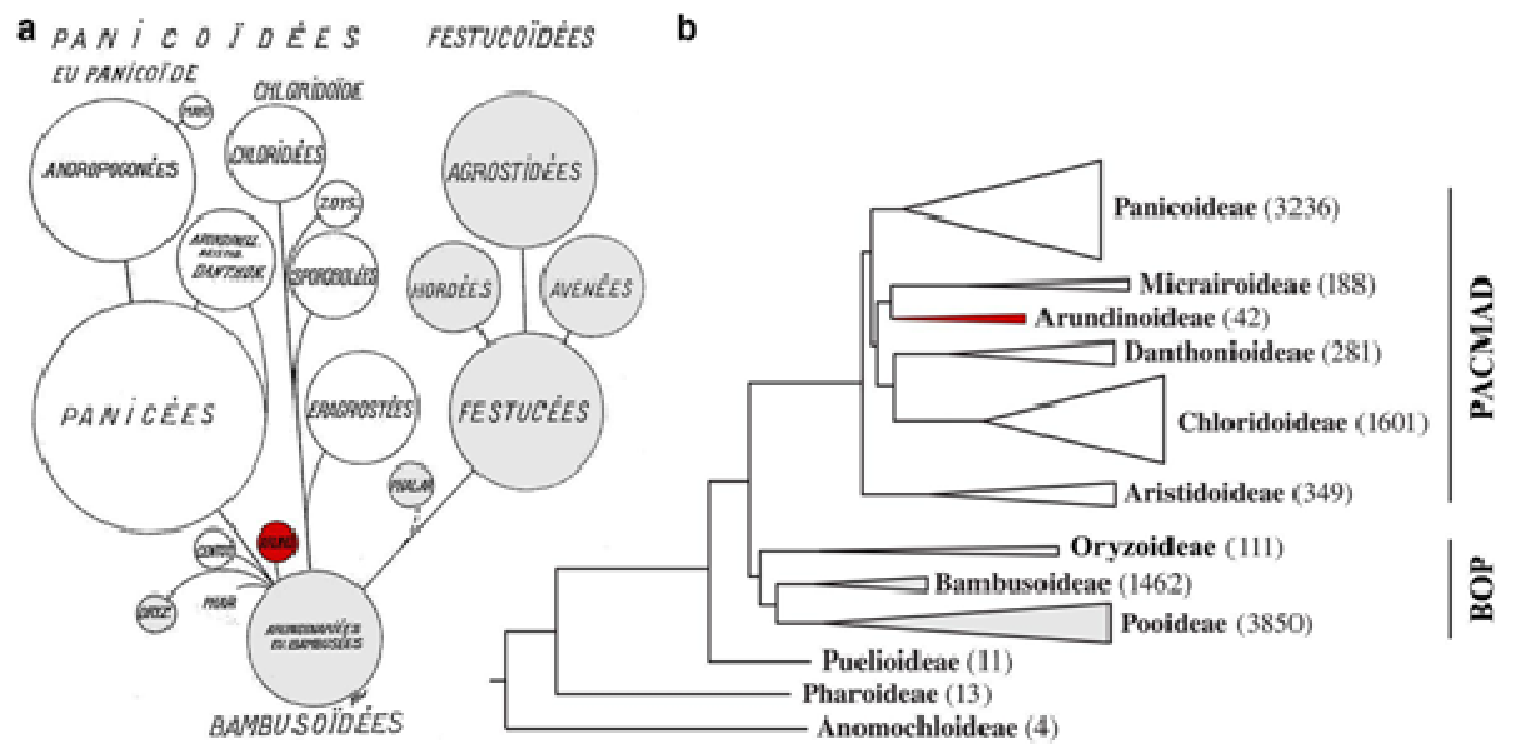

Fig. 1 Places of the Arundinoideae subfamily (in red) in the historical representation of grass systematics, from an old literature synthesis of morphological and anatomical studies (modified from Prat 1936; a) to a recent molecular phylogeny (modified from GPWG II 2012; b). Clade sizes are proportional to their species richness (also indicated between brackets). BOP clade, Bambusoideae-Oryzoideae- Pooideae (in grey); PACMAD clade, PanicoideaeAristidoideae- Chloridoideae-Micrairoideae-Arundinoideae-Danthonioideae (in white)

Table 1 Genera, species richness (S) and geographical distribution of the subfamily Arundinoideae

\begin{tabular}{lll}
\hline Genus & S & Distribution \\
\hline Amphipogon R.Br. (= Diplopogon R.Br.) & 9 & Australia \\
Arundo L. & 5 & Tropical Eurasia \\
Crinipes Hochst. & 2 & East Africa \\
Dichaetaria Nees ex Steud. & 1 & India \\
Dregeochloa Conert & 2 & South Africa \\
Elytrophorus P.Beauv. & 2 & Africa-Asia-Australia \\
Hakonechloa Makino ex Honda & 1 & Japan \\
Leptagrostis C.E.Hubb. & 1 & East Africa \\
Molinia Schrank (= Moliniopsis Hayata) & 3 & Eurasia \\
Monachather Steud. & 1 & Australia \\
Nematopoa C.E.Hubb. & 1 & South Africa \\
Phragmites Adans. & 5 & Cosmopolitan \\
Piptophyllum C.E.Hubb. & 1 & South Africa \\
Styppeiochloa De Winter & 3 & South Africa \\
*Zenkeria Trin. & 5 & India \\
Total & 42 & Old World + Australia \\
\hline
\end{tabular}

\footnotetext{
* Genus removed from the subfamily based on the present study
} 
The present study attempts to provide the first complete phylogeny of the Arundinoideae subfamily. The main challenges are (1) to test the monophyly of taxa currently included in Arundinoideae, (2) to resolve the phylogenetic relationships within this subfamily in order to identify putative tribes and (3) to initiate the understanding of the evolutionary history of this small but heterogeneous sub-family. To address this, we used five plastid DNA loci previously investigated to resolve the systematics of Poaceae. We also added previously published plastomes (complete plastid genomes) of several species, in order to increase the resolution of phylogenetic reconstructions and improve the calibration of molecular dating. Finally, we provide a taxonomic treatment to improve the classification of Arundinoideae.

\section{Materials and methods}

DNA extraction and plastid DNA sequencing

Sampling includes samples from BM, CANB, ETH, K, MARS, P, PRE and STR Herbaria (Online Resource 1). For each sample, about $1 \mathrm{~cm}^{2}$ of leaf material was crushed by two metallic marbles in 2-mL tubes treated with liquid nitrogen and placed in a ball mill. Total DNA was extracted following Doyle and Doyle (1987) with a modification for herbarium material: incubation of ground material with CTAB isolation buffer (4\% CTAB) for 120 min. DNA concentrations were estimated using a NanoDrop ND-1000 spectrophotometer (Labtech, Uckfield, UK) and diluted to $50 \mathrm{ng} / \mu \mathrm{L}$ for recent collections, or used at the initial concentration for old specimens with degraded DNA. Plastid DNA diversity was screened on five loci using primer couples as described in the literature and newly designed internal primers for specimens with degraded DNA: trn K$m a t \mathrm{~K}, m a t \mathrm{~K}, r b c \mathrm{~L}, r b c \mathrm{~L}-p s a \mathrm{I}, n d h \mathrm{~F}$ (Online Resource 2). Polymerase chain reactions (PCRs) were performed with $5 \mathrm{~mL}$ of DNA solution, $1 \times$ of GoTaq Flexi Buffer, $0.25 \mu \mathrm{M}$ of each primer (Eurofins Scientific, Luxembourg), $1.0 \mathrm{mM}$ of $\mathrm{MgCl}_{2}, 0.2 \mathrm{mM}$ of dNTP and 1 unit of GoTaq G2 Flexi DNA polymerase (Promega, Fitchburg, Wisconsin, USA) in a final volume of $50 \mu \mathrm{L}$. The thermal cycling profiles followed indications from the previously cited literature for each locus. Purification and sequencing of PCR products were carried out by Eurofins.

\section{Phylogenetic analyses}

First, each plastid DNA locus was manually checked and aligned in MEGA 6.0 (Tamura et al. 2013). In addition, we added corresponding sequences from four plastomes of Arundinoideae, three of Micrairoideae, four of Danthonioideae and five of Chloridoideae sequenced in a previous study (Cotton et al. 2015). Two 
nucleotide datasets were used: (1) the loci dataset including the five dissociated locus alignments and (2) the loci + plastome dataset gathering every locus in one large alignment with the 16 whole plastome sequences (Online Resource 3). In the second dataset, we combined the plastid sequences of Arundo donax L. with transcriptomic data from a previous study (GenBank accession GBRH01000000; Barrero et al. 2015), using the mapping function in Geneious v.7 and using the $P$. australis plastome as a reference (GenBank accession KF730315). The online program MAFFT v.7 was used for loci and plastomes alignments (http://mafft.cbrc.jp/alignment/server/; Katoh and Standley 2013). Phylogenetic relationships and dating divergences were estimated using Bayesian inferences in Beast v.1.8.1 (Drummond and Rambaut 2007). The Arundinoideae + Micrairoideae cluster was treated as the ingroup, and its monophyly was enforced as for the remaining outgroup and for the Danthonioideae and the Chloridoideae (GPWG II 2012). The molecular dating of phylogenetic divergences was led by a secondary calibration of basal nodes using dates and uncertainties estimated in previous analyses of angiosperm-wide datasets (Christin et al. 2013). These dates were obtained using several angiosperm fossils, with additional consideration of $67 \mathrm{Ma}$ fossilized phytoliths giving a lower age for the stem of Oryzeae (Prasad et al. 2011; Christin et al. 2013 ). Time constraints were set on the root of the tree by a normal distribution of mean $57.304 \pm 5.5$ and on the crown of Arundinoideae + Micrairoideae by a normal distribution of mean $47.509 \pm 8.5$. For each locus of the first dataset, unlink site models were estimated following substitution models indicated in jModelTest v.2.1 (Darriba et al. 2012), and unlink clock models were estimated under a log-normal relaxed clock with a normal distribution with the prior for the distribution of node ages approximated by a Yule speciation process (Table 2). The second dataset was analysed as a single alignment, following a general time-reversible substitution model with a gamma shape parameter and using a proportion of invariants $(G T R+G+I)$, and a log-normal relaxed clock with a Yule speciation process. The MCMC tree searches were run for 10,000,000 generations, sampling a tree every 1000 generations after a burn-in period of 1,000,000 generations. The adequacy of the number of generations, sampling frequency and burn-in period was confirmed through a visual inspection of the traces and ESS for all parameters using Tracer v.1.6 (Rambaut et al. 2017). Finally, the two maximum clade credibility (MCC) trees were summarized in TreeAnnotator 17.4 (Drummond et al. 2006).

Table 2 Characteristics of the plastid DNA loci used for phylogenetic reconstructions. Site models were defined for each locus using jModel-Test 2.1.10

\begin{tabular}{|c|c|c|c|c|c|c|c|}
\hline Locus & Length & Position & Site model & Substitution & e \% Identical sites & $\begin{array}{l}\text { Pairwise \% } \\
\text { identical sites }\end{array}$ & \% Indel sites \\
\hline trnK5'-matK5' & 736 & $3342-4078$ & TPM3uf + G & $1.28 \times 10^{-9}$ & 72.4 & 92.4 & 11.3 \\
\hline matK5 ${ }^{\prime}\left(-t r n K 3^{\prime}\right)$ & ) 1788 & $1553-3341$ & $\mathrm{GTR}+\mathrm{G}$ & $6.44 \times 10^{-10}$ & 82.9 & 96.9 & 1.19 \\
\hline$r b c \mathrm{~L}$ & 1321 & $61,833-63,154$ & $H K Y+I+G$ & $3.55 \times 10^{-10}$ & 90.8 & 98.0 & 1.74 \\
\hline$r b c \mathrm{~L}-p s a l$ & 1202 & $63,155-64,357$ & $\operatorname{TrN}+\mathrm{I}+\mathrm{G}$ & $1.18 \times 10^{-9}$ & 39.6 & 84.2 & 37.2 \\
\hline$n d h \mathrm{~F}$ & 2103 & $111,495-113,598$ & $\mathrm{GTR}+\mathrm{I}+\mathrm{G}$ & $7.56 \times 10^{-10}$ & 84.8 & 97.1 & 0.57 \\
\hline
\end{tabular}




\section{Results}

Our study presents 31 species with evidence from new plastid DNA sequences and includes two previously unsequenced genera, Crinipes Hochst. and Zenkeria. We failed to extract sufficiently preserved DNA or to find plant material in the visited herbaria for the monotypic genera: Dichaetaria (PRE980454), Leptagrostis (STR), Nematopoa (K) and Piptophyllum. The amplification of rbc L-psal failed for Amphipogon caricinus F.Muell. and one sample of D. pumila (PRE581482).

\section{Genetic variation of plastid DNA loci}

The five loci covered $7150 \mathrm{bp}$, i.e. $4.9 \%$ of the 146,502 bp represented by the plastomes alignment. The mapping of the $A$. donax transcriptome on the plastome of $P$. australis created a partial plastome of 78,561 bp for A. donax, i.e. $53.6 \%$ of the plastomes alignment, but including only low variability coding regions. In the first nucleotide dataset, the five loci show different amounts of variation, from low variable genes with less than $20 \%$ of variable sites (matK, $n d h \mathrm{~F}, r b c \mathrm{~L}$ ), to the intergenic spacer $r b c \mathrm{~L}-p s a$ l containing a high proportion of variable sites (60.4\%), among which a large portion of indels (37.2\% of sites), with a median variability for the mainly intronic trnK5'-matK5' (Table 2). The substitution varied from 3.55 to $7.56 \times 10^{-10}$ substitution per year for the three genes, and $1.18-1.28 \times 10^{-9}$ for the two other loci.

\section{Phylogenetic relationships}

The MCC trees generated from the two nucleotide datasets show almost identical and well resolved topologies, with nearly all nodes supported by posterior probabilities $>0.95$. In the Arundinoideae subfamily, three distinct and well supported clades can be identified: (1) the first one includes the Eurasian Arundo, the two Australian-endemic genera Amphipogon R.Br. and Monachather Steud., and the South African Dregeochloa Conert; (2) the second one includes sub-Saharan genera: Crinipes , Styppeiochloa De Winter, and Elytrophorus P.Beauv.; (3) the third one includes mainly Eurasian genera: Phragmites Adans., Molinia Schrank, and Hakonechloa Makino ex Honda. The only incongruence between the topologies generated by the two nucleotide datasets is located in the first clade, where the loci dataset describes early divergence of the Arundo-Monachather clade from the Amphipogon-Dregeochloa clade, whereas the loci + plastomes dataset shows the divergence of Amphipogon-Arundo from Monachather-Dregeochloa. In both phylogenies, these four putative clades are poorly supported ( $p p<0.7)$. The species currently known as ' $E$. 
walteri' is placed along a well-isolated stem as a sister group of the genus Elytrophorus, with a divergence estimated to $21.7 \mathrm{Ma}$ (or $16.8 \mathrm{Ma}$, for the loci dataset). The Micrairoideae subfamily appears as sister to the Arundinoideae. Surprisingly, genus Zenkeria is not included in Arundinoideae, but rather as the nearest relative of Micraira F.Muell. within Micrairoideae.

The two calibration strategies, considering (1) the five loci without plastome under unlink site and clock models, or (2) the whole alignment with plastomes following unique site and clock models, show a significant difference in divergence dating, with plastome calibration inducing older node ages in the ingroup (and younger ones in the outgroup) than unlinked calibration of the five loci, with a difference of about $5 \mathrm{Ma}$ (4-7 Ma) for a same node. The exception is the crown node of the whole chronogram supporting the dating calibration, remaining at $54.9 \mathrm{Ma}(95 \% \mathrm{Cl}[45.4 ; 65])$ for the loci + plastome dataset and $54.7 \mathrm{Ma} 95 \% \mathrm{Cl}$ [44.6; 65] for the loci dataset, near the prior at $57.3 \pm 5.5 \mathrm{Ma}$. The stem nodes of the three main clades previously described based on the loci + plastome dataset). Their crown nodes were estimated not so far from stem nodes, between 33 and38 Ma, expect for the crown node of clade Molinia-HakonechloaPhragmites, which is estimated around $15 \mathrm{Ma}(95 \% \mathrm{Cl}$ [27.6; 6.3]). Despite a large $95 \% \mathrm{Cl}$, every Arundinoideae genus started its diversification before the Quaternary, during the Neogene (23-2.6 Ma).

\section{Discussion}

\section{Resolution of Arundinoideae phylogeny}

The Arundinoideae subfamily appears here to be a robust evolutionary lineage of Poaceae, with eleven genera forming a monophyletic and structured clade. However, the present study shows that Zenkeria is misplaced and should reside in the Micrairoideae. We provide new molecular data for 12 genera of which two have never been sequenced but failed to analyse four other ones. These remaining four genera are monotypic, rare and have not been collected for a long time, but recent plastome sequencing data seem to place Dichaetaria, Nematopoa and Piptophyllum in other grass subfamilies (Teisher, pers. comm.). To date, Leptagrostis, known from only a few Schimper specimens collected over a century ago, has yet to be sequenced. During the present study, Kellogg (2015) mentioned three other genera in Arundinoideae: Alloeochaete C.E.Hubb., Danthonidium C.E.Hubb. and Phaenanthoecium C.E.Hubb., but these were placed as incertae sedis in the Danthonioideae by Soreng et al. (2015).

Even if the present study somewhat clarifies Arundinoideae systematics, this smaller refined subfamily remains oddly heterogeneous, with a variety of morphological forms and deep evolutionary differentiation among taxa, as suggested by the weak ratio between the numbers of species(41-42) and genera (11-14). 
Indeed, most genera include only 1 or $2(-3)$ species (Table 1), except Amphipogon (9) and the two reedy genera, Arundo (5) and Phragmites (5). Soreng et al. (2015) suggested further division into subtribes might be needed within the Arundinoideae. However, we chose to stay at a tribe level considering the limited interest in describing mono- or di-generic subtribes. With regard to the present phylogeny (Fig. 2), the structuring of the Arundinoideae into three tribes is well supported:

1. Tribe Molinieae V.Jirásek includes genera Hakonechloa, Molinia, and Phragmites (Jirásek 1966). Contrary to Soreng et al. (2015), we chose to remove the Crinipoid group (Barker 1997; Linder et al. 1997) from Molinieae based on the phylogenetic and morphological similarities of Hakonechloa, Molinia and Phragmites (supported by their stem length, recent diversification, and lemma similarity; Fig. 2). The Sino-Japanese Moliniopsis Hayata is sometimes considered as a distinct genus (Soreng et al. 2015) or placed as a synonym of Molinia based on morphological similarity (as in the present study). However, the $r p o \mathrm{C} 2, r b c \mathrm{~L}$ and $a t p \mathrm{~F}-a t p \mathrm{H}$ sequences deposited in GenBank for Moliniopsis japonica (Steud.) Hayata support placement within Molinieae, and molecular data fail to resolve the monophyly of Molinia and Moliniopsis (analyses not shown). The nine species of this tribe are primarily distributed in the Old World, but each of the three genera possesses an endemic taxon from Japan and surrounding areas: Hakonechloa macra (Munro) Honda, Molinia japonica Hack. and Phragmites japonicus Steud. Compared to the wider distribution of the five other species, this biogeographical pattern positions the early origin of this tribe towards Eastern Asia, with the Miocene formation of the Japan Sea (since $20 \mathrm{Ma}$ ) progressively inducing the Pliocene isolation (5-3 Ma) of Japanese Islands (Jolivet et al. 1994; Taira 2001; Isozaki et al. 2010). This late marine isolation may explain the parallel allopatric speciation of the three Japanese endemic taxa. The presence of long hairs on the callus (but not on the lemma) may be a synapomorphy characterizing Molinieae (Fig. 2), except for the short-haired or glabrous callus found in Molinia caerulea (L.) Moench.

2. Tribe Crinipedeae Hardion is described here to include Crinipes, Elytrophorus, Pratochloa (described here), and Styppeiochloa. This tribe corresponds to the Crinipoid group as described by Linder et al. (1997), except Zenkeria which we place in the Micrairoideae, and Dichaetaria, Nematopoa and Piptophyllum which should be moved to other subfamilies (Teisher, pers. comm.). Our new Crinipedeae poorly matches with subtribe Crinipinae Conert that included only Crinipes and Hakonechloa(Conert 1966). Both phylogenetic data and lemma morphology support a close relationship between the East African Crinipes and the South African Styppeoichloa. E. walteri, recently placed in the Arundinoideae based on nuclear and plastid sequences (Ingram et al. 2011), is sister to Elytrophorus. However, phylogenetic divergence and deep morphological differentiation of the lemma(Fig. 2) justify placement of this Namibian species in a new monotypic genus (see taxonomic treatment). The tribe Crinipedeae is mainly sub-Saharan (including Madagascar), except for Elytrophorus spicatus(Willd.) A.Camus which spreads to southern Asia and Australia. This large 
distribution pattern might be due to floral adaptations for long distance dispersal, e.g. by ornitochory since the lemmas have short, scabrous awns, the paleas are winged and variously notched (adherent), and this species grows in wet sites (a suitable condition for bird occurrence). Since CrinipesStyppeoichloa and Elytrophorus-Pratochloa form clades, it might be useful to eventually have this reflected in the classification, possibly as separate subtribes.

3. Tribe Arundineae Dumort. is also strongly supported in our phylogeny, even if supports of internal nodes among the four genera are weaker (Fig. 2). Initially included in the same genus due to their eco-morphological similarities, subtropical Eurasian reed genus Arundo does not belong to the same tribe as cosmopolitan reed genus Phragmites. Surprisingly, the taxa which are the closest relatives of Arundo are the two Australian-endemic herbaceous genera Amphipogon and Monachather (Barker et al. 1995). The present study also places the South African genus Dregeochloa in Arundineae, and not in Molinieae as assumed by Soreng et al. (2015). The morphological similarities between Dregeochloa and Monachather (Fig. 2) and the biogeographical afnities between Amphipogon and Monachather might justify the use of Amphipogoneae L.Watson and T.D.Macfarl., thus isolating Arundo in the Arundineae. However, these assumptions need to be tested using other molecular markers, and specifically with nuclear genes that have been poorly investigated in this subfamily (Hsiao et al. 1998). The Australian genus Amphipogon includes the highest species richness of Arundinoideae genera, with nine species radiating in the West Mediterranean zone of Australia, with several endemic taxa and some species with a broader distribution in Eurasia. 


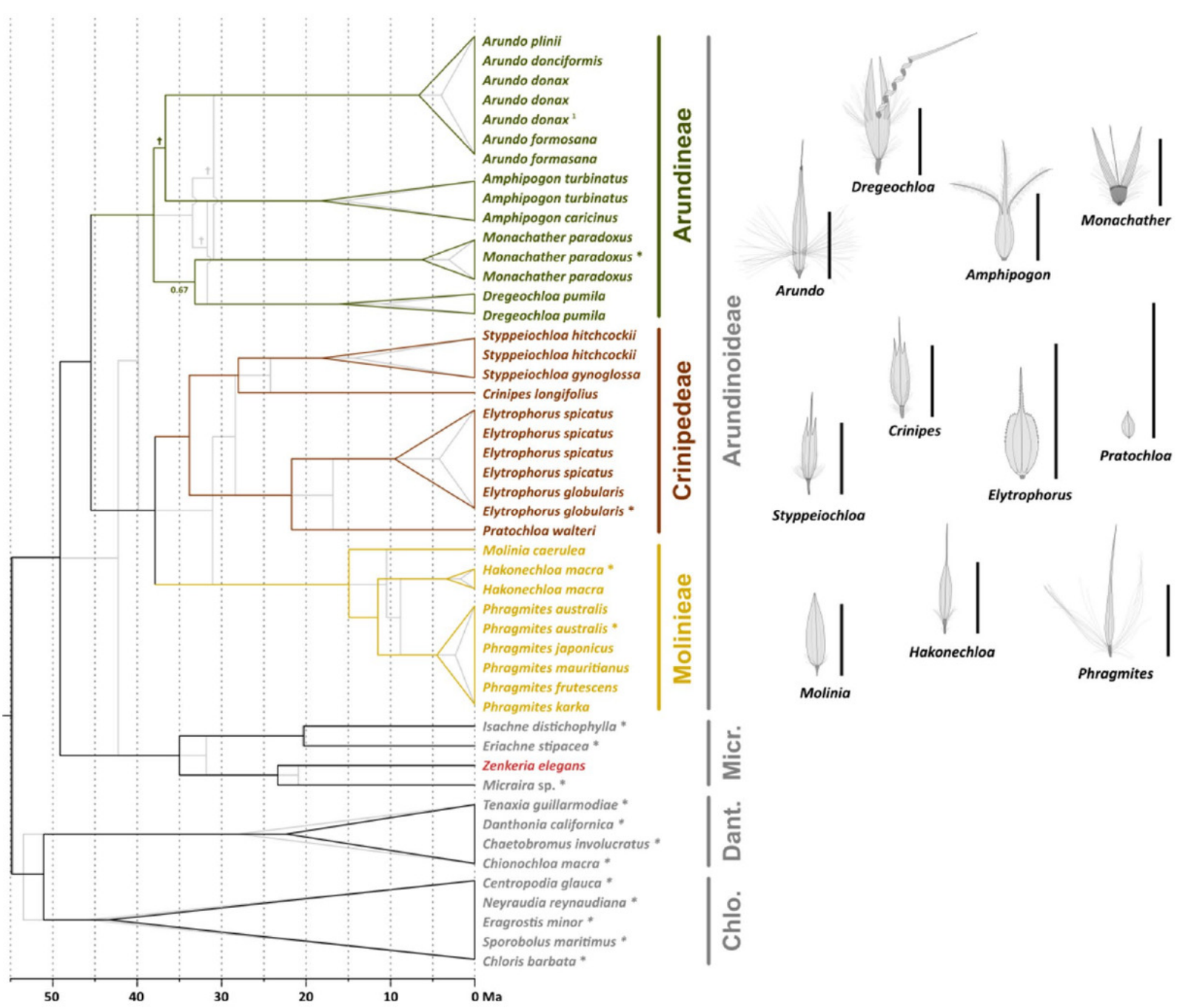

Fig. 2 Chronogram of Arundinoideae based on five plastid DNA loci (trnK-matK, matK, rbcL, rbcL-psal, ndhF) and plastomes data (asterisk), and morphological diversity of lemmas within this small subfamily. Molecular clock secondarily calibrated using previous estimations from Christin et al. (2013) for the two divergence nodes with outgroup Micrairoideae (Micr.) and outgroup Chloridoideae (Chlo.) + Danthonoideae (Dant.). Grey phylogeny indicated the same chronogram without plastome data and considering unlinked site and clock models for each locus. Nodes without value are supported by posterior probabilities of 1.0, and nodes with cross symbols (dagger) are supported by posterior probabilities between 0.7 and 1.0. Black bars, $5 \mathrm{~mm}$. ${ }^{1}$ Partial plastome of Arundo donax (coding regions covering $53.6 \%$ of the plastome alignment) from transcriptome data (Barrero et al. 2015)

It is noteworthy that Arundinoideae initially described on the basis of reedy genera such as Arundo, Phragmites and Molinia (also called the Phragmitiformes Avdulov 1931) cannot exclusively be considered a reedy group of grasses. The high number of small herbaceous taxa and the distant position of Arundo and Phragmites argue for the homoplasy of culm height and rigidity. However, most Arundinoideae taxa are associated with humid habitats, even when they occur in semi-arid biomes. Dregeochloa is a counterexample of this, with its distribution in arid zones, and several xerophyte adaptations (thickened cuticle, stomata protection, succulent leaves; accurate description in Ellis 1977). 
In a global consideration, except for North American native P. australis subsp. americanus Saltonstall, P.M. Peterson \& Soreng (Saltonstall et al. 2004), Arundinoideae are restricted to the Old World (including Australia). The biogeography of Arundinoideae looks like a Gondwanan legacy, with South and East African, Indian and Australian species. Consequently, hypotheses of vicariance and/or land dispersal have yet to be tested (e.g. Linder et al. 1997). However, the removal of Indian endemic, Zenkeria and our molecular dating shed new light on the subject. Indeed, these geological zones were clearly isolated by the Indian Ocean 100 Ma ago (Crisp and Cook 2013), long before the stem node of the Arundinoideae. Consequently, the common ancestors of this subfamily had to possess some suitable traits for long distance dispersal, e.g. by anemochory, as illustrated by the long-haired lemma inclosing small caryopses and forming an efficient means for dispersal (e.g. Phragmites, Arundo, Fig. 2), or by ornitochory as suggested above for Elytrophorus spicatus or other species growing in wet sites; or by marine dispersal as sometimes hypothesized for Phragmites (Lambertini et al. 2012).

\section{Taxonomic treatment}

subfam. Arundinoideae Kunth ex Beilschm.

$=$ Arundinoideae Tateoka

= Phragmitoideae Parodi ex Caro

= Arundinaceae Burmeist., unranked

tribe Arundineae Dumort.-TYPE: Arundo L.

$=$ Amphipogoneae L.Watson \& T.D.Macfarl.

= subtribe Arundininae Miq.

Genera included: Amphipogon R.Br. (= Diplopogon R.Br.), Arundo L., Dregeochloa Conert, Monachather Steud. 
tribe Molinieae Jirásek-TYPE: Molinia Schrank

Genera included: Hakonechloa Makino ex Honda, Molinia Schrank (= Moliniopsis Hayata), Phragmites Adans.

tribe Crinipedeae Hardion, trib. nov.-TYPE: Crinipes Hochst.

$=$ Crinipinae Conert pro parte.

Description: Annual or perennial erect herbs, culms $10-150 \mathrm{~cm}$ long. Ligule a fringe of hairs or an eciliate membrane. Leaves mostly basal or cauline, non-auriculate. Leaf blades stiff, persistent or deciduous. Leaf sheaths persistent. Panicle open or glomerate. Fertile spikelets laterally compressed, 2-12 mm long, comprising 2-15 florets, breaking up at maturity, disarticulating below each fertile floret, with diminished florets at the apex. Rachilla internodes definite. Glumes persistent, shorter than spikelet, ovate or lanceolate. Lower glume shorter than to equal to upper glume. Glumes 1-keeled and 1-3-veined. Lemma membranous, with or without keel, 3-veined, entire or dentate bifid. Lodicules 2, Stamens 3.

Genera included: Crinipes Hochst., Elytrophorus P.Beauv., Pratochloa Hardion, Styppeiochloa De Winter.

Pratochloa Hardion, gen. nov. इ Eragrostis walteri Pilg. - TYPE: Pratochloa walteri (Pilg.) Hardion

Pratochloa walteri (Pilg.) Hardion, comb. nov. $\equiv$ E. walteri Pilg., Notizbl. Bot. Gart. Berlin-Dahlem 15: 452. 1940. -TYPE: NAMIBIA. Kleiner Naukluftrivier, 29 Oct 1937, Walter 458 (holotype: B [image B100272776!]; isotype: B [image B100272777!])

Etymology: This new genus is named in tribute to Henri Prat (1902-1981), professor at the Universities of Marseille (France) and Montreal (Quebec, Canada). After a thesis on the systematic study of grass epidermises, he published several works on the systematics of Poaceae with an emphasis on their morphology, anatomy and organogenesis (Prat 1932, 1936, 1960). 
Acknowledgements The authors thank staffs from BM, CANB, ETH, K, MARS, P, PRE and STR Herbaria for loans and material removal. LH addresses a special thanks to Pascal-Antoine Christin (University of Sheffield) for data and support in the calibration of the molecular phylogeny, and to Jordan Teisher (Washington University in St. Louis) for useful and sporting exchange views about the systematics of Arundinoideae. The authors are also grateful to Marianick Juin (IMBE) for contribution in the lab work, to Heather Lindon (RBG Kew) for expertise in botanical Latin, and to Paul M. Peterson (US, Smithsonian Institution) for his conscientious review which greatly improved the readability of the manuscript.

\section{Compliance with ethical standards}

Confict of interest The authors declare that they have no conflict of interest.

Ethical statement The authors comply will all rules of the journal following the COPE guidelines; all authors have contributed and approved the final manuscript.

\section{Information on Electronic Supplementary Material}

Online Resource 1. Sampling information and GenBank accessions.

Online Resource 2. Primers used in PCRs and developed for the present study.

Online Resource 3. Loci + plastome alignment used for phylogenetic analyses.

\section{References}

Auquier P (1963) Critères anciens et modernes dans la systématique des Graminées. Natura Mosana 16:1-63

Avdulov NP (1931) Karyo-systematische Untersuchungen der Familie Gramineen. Bull Appl Bot Suppl 44:1428

Barker NP (1997) The relationships of Amphipogon, Elytrophorus and Cyperochloa (Poaceae) as suggested by $r b c L$ sequence data. Telopea 7:205-213 
Barker NP, Linder HP, Harley EH (1995) Polyphyly of Arundinoideae (Poaceae): evidence from rbcL sequence data. Syst Bot 20:423-435. doi:10.2307/2419802

Barker NP, Linder HP, Harley EH (1998) Sequences of the grass-specific insert in the chloroplast rpoC2 gene elucidate generic relationships of the Arundinoideae (Poaceae). Syst Bot 23:327-350. doi:10.2307/2419509

Barrero RA, Guerrero FD, Moolhuijzen P, Goolsby JA, Tidwell J, Bellgard SE, Bellgard MI (2015) Shoot transcriptome of the giant reed, Arundo donax. Data Brief 3:1-6. doi:10.1016/j. dib.2014.12.007

Brown R (1810) Prodromus florae Novae Hollandiae et insulae Van-Diemen. J. Johnson, London

Brown R (1814) General remarks, geographical and systematical, on the botany of Terra Australis. In: Flinders M (ed) A voyage to Terra Australis: undertaken for the purpose of completing the discovery of that vast country, and prosecuted in the years 1801, 1802, and 1803. W. Bulmer, London, pp 580-583 (appendix 3)

Christin PA, Spriggs E, Osborne CP, Strömberg CA, Salamin N, Edwards EJ (2013) Molecular dating, evolutionary rates, and the age of the grasses. Syst Biol 63:153-165. doi:10.1093/sysbio/ syt072

Clark LG, Zhang W, Wendel JF (1995) A phylogeny of the grass family (Poaceae) based on $n d h F$ sequence data. Syst Bot 20:436-460. doi:10.2307/2419803

Clayton WD, Renvoize SA (1986) Genera graminum: grasses of the world. Kew Bull Addit Ser 13:1-389

Conert HJ (1961) Die Systematik und Anatomie der Arundinae. Verlag von J. Cramer, Weinheim

Conert HJ (1966) Dregeochloa, eine neue Gattung der Gramineen (Gramineae, Arundinoideae, Danthonieae). Senckenberg Biol 47:35-43

Cotton JL, Wysocki WP, Clark LG, Kelchner SA, Pires JC, Edger PP, Mayfield-Jones D, Duvall MR (2015) Resolving deep relationships of PACMAD grasses: a phylogenomic approach. BMC PI Biol 15:178. doi:10.1186/s12870-015-0563-9

Crisp MD, Cook LG (2013) How was the Australian flora assembled over the last 65 million years? A molecular phylogenetic perspective. Annual Rev Ecol Evol Syst 44:303-324. doi:10.1146/ annurev-ecolsys$110512-135910$

Darriba D, Taboada GL, Doallo R, Posada D (2012) jModelTest 2: more models, new heuristics and parallel computing. Nat Meth 9:772. doi:10.1038/nmeth.2109 
Doyle JJ, Doyle JL (1987) A rapid DNA isolation procedure for small quantities of fresh leaf tissue. Phytochem Bull 19:11-15 Drummond AJ, Rambaut A (2007) BEAST: Bayesian evolutionary analysis by sampling trees. BMC Evol Biol 7:214. doi:10.1186/1471-2148-7-214

Drummond AJ, Ho SY, Phillips MJ, Rambaut A (2006) Relaxed phylogenetics and dating with confidence. PLoS Biol 4:e88. doi:10.1371/journal.pbio.0040088

Duvall MR, Morton BR (1996) Molecular phylogenetics of Poaceae: an expanded analysis of $r b c L$ sequence data. Molec Phylogen Evol 5:352-358. doi:10.1006/mpev.1996.0030

Ellis R (1977) Leaf anatomy of the South African Danthonieae (Poaceae). I. The genus Dregeochloa. Bothalia $12: 209-213$

Grass Phylogeny Working Group (GPWG) (2001) Phylogeny and subfamilial classification of the grasses (Poaceae). Ann Missouri Bot Gard 88:373-457. doi:10.2307/3298585

Grass Phylogeny Working Group II (GPWG II) (2012) New grass phylogeny resolves deep evolutionary relationships and discovers C4 origins. New Phytol 193:304-312. doi:10.1111/j.1469-8137.2011.03972.x Hilu KW, Alice LA, Liang H (1999) Phylogeny of Poaceae inferred from matK sequences. Ann Missouri Bot Gard 86:835-851. doi:10.2307/2666171

Hsiao C, Jacobs SWL, Barker NP, Chatterton NJ (1998) A molecular phylogeny of the subfamily Arundinoideae (Poaceae) based on sequences of rDNA. Austral Syst Bot 11:41-52. doi:10.1071/ SB97001

Hsiao C, Jacobs SWL, Chatterton NJ, Asay KH (1999) A molecular phylogeny of the grass family (Poaceae) based on the sequences of nuclear ribosomal DNA (ITS). Austral Syst Bot 11:667-688. doi:10.1071/SB97012 Ingram AL, Christin PA, Osborne CP (2011) Molecular phylogenies disprove a hypothesized $-\mathrm{C}_{4}$ reversion in Eragrostis walteri (Poaceae). Ann Bot (Oxford) 107:321-325. doi:10.1093/aob/ mcq226

Isozaki Y, Aoki K, Nakama T, Yanai S (2010) New insight into a subduction-related orogen: a reappraisal of the geotectonic framework and evolution of the Japanese Islands. Gondwana Res 18:82-105

Jacques-Félix H (1958) IX - Notes sur les graminées d’Afrique tropicale. J Agric Trop Bot Appl 5:304-307

Jirásek V (1966) The systematics of cultivated plants and their taxonomic categories. Preslia 38:267-284 
Jolivet L, Tamaki K, Fournier M (1994) Japan Sea, opening history and mechanism: a synthesis. J Geophys Res Solid Earth 99:22237-22259. doi:10.1029/93JB03463

Katoh K, Standley DM (2013) MAFFT multiple sequence alignment software version 7: improvements in performance and usability. Molec Biol Evol 30:772-780. doi:10.1093/molbev/mst010

Kellogg EA (2000) The grasses: a case study in macroevolution. Annual Rev Ecol Syst 31:217-238. doi:10.1146/annurev. ecolsys.31.1.217

Kellogg EA (2015) Flowering plants. Monocots: Poaceae, vol. 13. Springer, Berlin

Lambertini C, Mendelssohn IA, Gustafsson MH, Olesen B, Tenna RIIS, Sorrell BK, Brix H (2012) Tracing the origin of Gulf Coast Phragmites (Poaceae): a story of long-distance dispersal and hybridization. Amer J Bot 99:538-551. doi:10.3732/ ajb.1100396

Linder HP, Verboom GA, Barker NP (1997) Phylogeny and evolution in the Crinipes group of grasses (Arundinoideae: Poaceae). Kew Bull 52:91-110. doi:10.2307/4117843

Prasad V, Strömberg CAE, Leaché AD, Samant B, Patnaik R, Tang L, Mohabey DM, Ge S, Sahni A (2011) Late Cretaceous origin of the rice tribe provides evidence for early diversification in Poaceae. Nat Commun 2:480. doi:10.1038/ncomms1482

Prat H (1932) L'épiderme des Graminées. Étude anatomique et systématique. Ann Sci Nat Bot 14:117-324

Prat H (1936) La systématique des Graminées. Ann Sci Nat Bot 18:165-258

Prat H (1960) Vers une classification naturelle des Graminées. Bull Soc Bot France 107:32-79

Rambaut A, Suchard M, Drummond A (2017) Tracer, version 1.6. Available at:

http://tree.bio.ed.ac.uk/software/tracer/

Renvoize SA (1981) The sub-family Arundinoideae and its position in relation to a general classification of the Gramineae. Kew Bull 36:85-102. doi:10.2307/4119008

Saltonstall K, Peterson PM, Soreng RJ (2004) Recognition of Phragmites australis subsp. americanus (Poaceae: Arundinoideae) in North America: evidence from morphological and genetic analyses. Sida 21:683-692 
Sánchez-Ken JG, Clark LG, Kellogg EA, Kay EE (2007) Reinstatement and emendation of subfamily Micrairoideae (Poaceae). Syst Bot 32:71-80. doi:10.1600/036364407780360102

Shantz HL (1954) The place of grasslands in the Earth's cover. Ecology 35:143-145. doi:10.2307/1931110

Soreng RJ, Peterson PM, Romaschenko K, Davidse G, Zuloaga FO, Judziewicz EJ, Filgueiras TS, Davis JI, Morrone O (2015) A worldwide phylogenetic classification of the Poaceae (Gramineae). J Syst Evol 53:117137. doi:10.1111/jse.12150

Stebbins GL, Crampton B (1959) A suggested classification of grass genera of North America based on modern criteria. Congr Int Bot 9th 2:378-379

Taira A (2001) Tectonic evolution of the Japanese island arc system. Annual Rev Earth Planet Sci 29:109-134. doi:10.1146/annurev. earth.29.1.109

Tamura K, Stecher G, Peterson D, Filipski A, Kumar S (2013) MEGA6: molecular evolutionary genetics analysis version 6.0. Molec Biol Evol 30:2725-2729. doi:10.1093/molbev/mst197

Electronic supplementary material The online version of this article (doi:10.1007/s00606-017-1451- 6) contains supplementary material, which is available to authorized users. 